\title{
Students' Perceptions and Expectation Gap on the Skills and Knowledge of Accounting Graduates
}

\author{
Cornelia ARYANTI ${ }^{1}$, Desi ADHARIANI ${ }^{2}$
}

Received: June 23, 2020 Revised: July 12, 2020 Accepted: August 10, 2020

\begin{abstract}
This study aims to describe the perceptions of accounting students and expectations of employers towards the skills and knowledge needed by accounting graduates in Indonesia. Quantitative method using survey is employed to analyze 103 questionnaires from students and 51 questionnaires from employers. The results showed that students' perceived honesty, continuous learning, and work ethics are important skills, while employers stress the importance of work ethics, teamwork, and time management. Knowledge needed by accounting graduates in the perception of students includes financial accounting, financial reporting, and financial statement analysis, whereas employers perceived the importance of financial statement analysis, knowledge of Microsoft Office program, and financial accounting. Further analysis showed that there is an expectation gap between the perceptions of students and the expectations of employers towards skills - not knowledge - needed by accounting graduates. Although investigations of students' perceptions and employers' expectations have been conducted in previous studies, the information should be updated continuously to reflect the current conditions. This study offers the recent perceptions from students and employers to identify the current expectation gap. This study points to the importance of skills development in the university curriculum in order to develop the skillful human resources in accounting and meet the expectations of employers.
\end{abstract}

Keywords: Accounting Skills, Accounting Knowledge, Accounting Students, Employer, Expectation Gap

JEL Classification Code: M12, M49, M51

\section{Introduction}

Skills and professional knowledge of accounting required as well as information about the development of the business world can be obtained through, among others, education in college. Therefore, accounting study programs should ideally provide relevant educational services to make

${ }^{1}$ First Author. Department of Accounting, Faculty of Economics and Business, Universitas Indonesia, Kampus UI Depok, Indonesia. Email: cornelia.aryanti91@gmail.com.

${ }^{2}$ Corresponding Author. Department of Accounting, Faculty of Economics and Business, Universitas Indonesia, Kampus UI Depok, Indonesia [Postal Address: Jl. Margonda Raya, Pondok Cina, Kecamatan Beji, Kota Depok, Jawa Barat 16424, Indonesia] Email: desi.adhariani@ui.ac.id ; desiadharis@gmail.com

(c) Copyright: The Author(s)

This is an Open Access article distributed under the terms of the Creative Commons Attribution Non-Commercial License (https://creativecommons.org/licenses/by-nc/4.0/) which permits unrestricted non-commercial use, distribution, and reproduction in any medium, provided the original work is properly cited. students feel attracted to accounting professions and compete in the global economy. Kavanagh and Drennan (2008) states that students need to be aware that employers have expectations of skills possessed by graduates of accounting in terms of communication, analysis, professionalism, and teamwork. Although employers expect accounting graduates to have a good understanding of basic accounting skills and strong analytical skills, business awareness and knowledge in the real world of work are much preferred. Analysis of thinking processes and communication skills of accounting graduates are much needed compared to grades obtained during the study.

Employers have complained that they are disappointed over the skills and knowledge of graduates of accounting from universities (Kumari, 2014). This has resulted in a gap in the form of conflicting views between employers and students about the skills that must be mastered by accounting graduates. According to the research by Kavanagh and Drennan (2008), the expectation gap between the perception 
of students and expectation of employers with regard to the important skills needed by graduates arises because the views of accounting educators are not in line with employers' viewpoint resulting in different perceptions of employers. However, Low et al. (2016) dismisses the expectation gap posited in the previous study. According to this study, more than half of employers believe that universities have appropriately prepared students to be ready for work. This study is in line with the studies in Indonesia, which show that there is no gap between the perspective of students, accounting lecturers and employers in terms of the skills required by accounting graduates. The criteria for employers in this study are accounting staff in various companies with the minimum education of bachelor's degree.

The above explanation motivates the researcher to examine the perception of accounting graduates in an outstanding university in Indonesia and expectation of employers with regard to, not only the skills, but also the knowledge required by graduates. The criteria employers used are workers having an equal position as supervisor and, above all, drawing a definition of employer more representative and the results more relevant. This study examines what should be the highest priority, regarding skills and knowledge that should be mastered by accounting graduates, according to the students, and the skills and knowledge expected of them by employers, and the existence of the expectation gap. To achieve this objective, a literature review is presented first, followed by the research method, then, findings and analysis, and lastly, conclusion.

\section{Literature Review}

\subsection{Perception}

Perception in the unabridged dictionary of psychology is defined as a process of observing a person in the environment by using the senses mastered so that the person becomes aware of everything that exists in the environment. The impression obtained by the individual through the five senses is analyzed (organized), interpreted, and then evaluated so that the individual acquires meaning (Robbins, 2008). Individuals are required to provide an assessment of an object that can be positive or negative, happy or unhappy, and so on. This assessment will shape the attitude, which is a stable tendency to act or to act in a particular situation (Polak, 1976).

\subsection{Expectation}

Etymologically, the word expectation comes from the word 'expectation' in English, which means hope (The Fourth Issue of the Dictionary of Indonesian Language).
The expectation is also defined as future-centered beliefs that are most likely to come true. The expectation is something someone expects from something. The expectation to produce a work at any given time depends on the specific goals and also understanding of the value of work achievement as a tool for achieving that goal.

\subsection{Expectation of Employers}

Research on the expectation of employers from accounting graduates suggests that they do not fulfill non-technical skills, but rather have more technical skills (Kavanagh \& Drennan, 2008). Several non-technical skills that are not fulfilled by accounting graduates are teamwork skills, interpersonal skills, creative skills, and communication skills, both oral and written. In addition, Bui and Porter (2010) note that job seekers score high marks on the personality of graduates in harmony with corporate culture and potential of them showing the willingness to continual learning. Klibi and Oussii (2013) suggest that job seekers are also looking for life experiences in accounting graduates. Meanwhile, Jackling and de Lange (2009) assert that accounting graduates are lacking leadership.

Developing broader accounting skills through the incorporation of emotional intelligence and non-technical skills into the curriculum is also important. The importance of emotional intelligence is advisable to accounting educators to modify their curriculum to increase opportunities for graduates to work in Big Four firms (Deloitte, Ernst \& Young, KPMG, PwC). Unlike the 'Big Four' firms, smaller firms prioritize good technical skills and interpersonal skills than oral presentation skills, writing skills, and analytical skills. A study conducted by Tempone et al. (2012) in Australia indicates that non-technical skills are expected to fit the business sector of the company. Therefore, the skills and attributes of accounting that job seekers seek are discursive, namely, findings that are relatively diverse and very different according to the research context.

\subsection{Expectation Gap}

Different backgrounds will produce different views, such as understanding of the meaning between the employer and the students about the skills that accounting graduate must possess. This gap is called the 'expectation gap' or the gap of hope. From this definition, we can construe the expectation gap as the difference between the wishes or expectations of the community towards the work of an auditor with the work shown by the auditor. Koh and Woo (1998) explain that expectation gap can arise because of two situations: 
1. The reasonable gap is the gap between what the public wants the auditor to accomplish and what the auditor can expect to do appropriately.

2. The performance gap is the gap between what the public would expect an auditor to do properly with what the auditor understands to achieve.

This study observes whether there is an expectation gap between the employer and the students in their perception of the skills and knowledge required by accounting graduates. The difference lies in the needs of employers and the ability of graduates to show their lack of skills and the features expected by employers (Jackling \& de Lange, 2009). Kavanagh and Drennan (2008) provide evidence that job seekers have found that accounting graduates are not ready for work. Other studies have even suggested that the gap between education and practice is very wide (Albrecht \& Sack, 2000).

\subsection{Skills}

Skill is the ability to operate jobs easily and meticulously (Gordon, 1994). According to Nadler (1986), the definition of skill is an activity that requires practice or can be interpreted as an implication of the activity. Meanwhile, according to Dunnette (1976), skill is the capacity needed to perform some tasks that are the development of training results and experience gained. The skills in this study are measured through 21 attributes based on the literature review studied by Uyar and Gungormus (2011)

\subsection{Knowledge}

Keraf (2001) notes that knowledge constitutes all human thoughts, ideas, concepts, and understanding. If a person is an economist, then the knowledge to be mastered are the concepts and theories of economics. In addition, an autonomous person should also be able to analyze social issues related to his expertise. Accounting graduates are required to have knowledge such as financial statement analysis, financial accounting, financial reporting standards, including the basic principles and concepts of accounting (Bakar \& Bakar, 2020) to increase competencies prior to the uptake in the job market (Tresnaningsih et al., 2020). Therefore, before applying for a job, accounting graduates should prepare themselves by developing and deepening accounting knowledge while studying in college. The accounting knowledge in this study is measured through 22 knowledge attributes based on the list of courses taught at the Turkish Vocational School and Faculty of Economics and Business of the Business and Accounting Department studied by Uyar and Gungormus (2011).

\section{Research Methods}

\subsection{Research Design}

This study uses quantitative methods because the data in the study can be calculated or measured and analyzed using statistics. The type of quantitative methods used in this research is the descriptive type, which describes the situation or occurrence about the certain character of population precisely and accurately.

\subsection{Data Collection Method}

The primary data is obtained using survey method by distributing questionnaires.

\subsection{Variable Operationalization}

The operationalization of skill variable, shown in Table 1, to find out student perception, consisting of 21 items; the operationalization of knowledge variable, shown in Table 2, to know the expectation of employers, consisting of 22 points of knowledge.

Table 1: Operationalization of Variables of Skills

\begin{tabular}{|c|l|c|}
\hline \multirow{2}{*}{ Number } & \multirow{2}{*}{ Skill } & Measuring \\
\hline 1 & Honesty & Likert \\
\hline 2 & Work ethics & $(1-5)$ \\
\hline 3 & Teamwork & STP-SP \\
\hline 4 & Ethical awareness & \\
\hline 5 & Continuous learning & \\
\hline 6 & Analytical thinking & \\
\hline 7 & Interpersonal communication skills & \\
\hline 8 & Time management & \\
\hline 9 & Problem-solving abilities & \\
\hline 10 & Comprehension of responsibilities & \\
\hline 11 & Oral communication skills & \\
\hline 12 & Critical thinking & \\
\hline 13 & Stress management & \\
\hline 14 & Written communication skill & \\
\hline 15 & Decision-making & \\
\hline 16 & Report writing & \\
\hline 17 & Self-motivation & \\
\hline 18 & Flexibility & \\
\hline 19 & Loyalty to the institution & \\
\hline 20 & Presentation skills & \\
\hline 21 & Mastering accounting software & \\
\hline
\end{tabular}

Source: modified by researchers based on Uyar and Gungormus (2011) 
Table 2: Operationalization of Variables of Knowledge

\begin{tabular}{|c|c|c|}
\hline \multirow{2}{*}{ Number } & \multirow{2}{*}{ Knowledge } & Measuring \\
\hline & & Scale \\
\hline 1 & Microsoft Office Program (word, excel, ...) & Likert \\
\hline 2 & Auditing & $(1-5)$ \\
\hline 3 & Accounting and Financial Reporting Standards & STP-SP \\
\hline 4 & Financial Statement Analysis & \\
\hline 5 & Financial Accounting & \\
\hline 6 & Capital Market Board Regulations & \\
\hline 7 & Cost Accounting & \\
\hline 8 & Managerial Accounting & \\
\hline 9 & Ethics of Accounting Profession & \\
\hline 10 & Corporate Accounting & \\
\hline 11 & Tax Regulations & \\
\hline 12 & Finance & \\
\hline 13 & Business Law & \\
\hline 14 & Accounting Information System & \\
\hline 15 & Business Mathematics & \\
\hline 16 & Statistics and Quantitative Methods & \\
\hline 17 & Computerized Accounting & \\
\hline 18 & Construction Accounting & \\
\hline 19 & Bank Accounting & \\
\hline 20 & Insurance Accounting & \\
\hline 21 & Hospitality Accounting & \\
\hline 22 & Public Sector Accounting & \\
\hline
\end{tabular}

Source: modified by researchers based on Uyar and Gungormus (2011)

\subsection{Population}

The population of this study is students of the undergraduate degree in Accounting and employers in Jakarta, Indonesia.

\subsection{Sampling Technique}

The sampling technique uses non-probability sampling by distributing questionnaires with purposive sampling technique. The population in this study is accounting students and employers. The perceptions of students and employers in the capital city are expected to set as a benchmark on the students' perceptions. Below are the selection sample criteria determined by researchers.

1. Undergraduate accounting students are students who are in the third year of regular and parallel programs, namely, classes of 2013 and 2014 and extension program students' classes of 2014, 2015, and 2016. This selection is based on the assumption that the students have taken accounting courses and have an idea of the professional world. 
2. Employers who have the minimum positions equivalent to a supervisor and above in various industry companies in the field of accounting. This selection is based on the authority of the employer at the level of supervisor and above in the recruitment of prospective employees graduating from accounting study program.

\subsection{Method of Data Processing and Analysis}

The data in this research is processed using SPSS version 21.0 software through several tests. The tests conducted are validity and reliability test, descriptive analysis, independent t-test analysis, and One-Way ANOVA analysis.

\section{Results and Discussion}

\subsection{Results of Sampling}

The research questionnaires are distributed through instant messaging application using Google form and directly in a physical form to accounting students in Jakarta, at least students who are in the third year of regular program and students of parallel program and extension program classes of 2014, 2015, and 2016. In addition, the questionnaires for employers are distributed through instant messaging applications and e-mail. The questionnaires through Google form are only filled by four students and 122 employers, so that the data is quite valid, while physical questionnaires are distributed to 130 students. However, only 99 questionnaires returned from students and 51 questionnaires returned from employers that can be processed - questionnaires form four student were not complete, 27 students did not return their questionnaires, and 71 questionnaires from employers did not meet job qualification. The total number of questionnaires that could be processed was 103 questionnaires from students and 51 questionnaires from employers.

Table 3: Total Questionnaires Distributed

\begin{tabular}{|l|c|c|}
\hline Number of Questionnaire & Student & Employer \\
\hline $\begin{array}{l}\text { Hard copy questionnaire } \\
\text { distributed }\end{array}$ & 130 & \\
\hline Questionnaire not returned & $(27)$ & \\
\hline Questionnaire returned & 103 & \\
\hline Questionnaire not filled & $(4)$ & \\
\hline Hard copy questionnaire filled & 99 & \\
\hline Online questionnaire & 4 & 122 \\
\hline $\begin{array}{l}\text { Questionnaire not meeting the } \\
\text { requirements }\end{array}$ & 103 & $(71)$ \\
\hline \multicolumn{1}{|c|}{ Total } & 51 \\
\hline
\end{tabular}

\subsection{Profile of Students Respondents}

Profile of respondents can be found in the first part of the questionnaire. The profile of student respondents includes undergraduate degree, gender, admission year, work/internship experience, length of work/internship, and type of work/internship industry. Meanwhile, the profile of employer respondents includes gender, age, length of work experience, type of workplace industry and position. Information about the respondent's profile is important for processing the data and comparing the results of the data from these two populations.

Out of 103 respondents filling the questionnaire, 23 $(22.33 \%)$ come from regular undergraduate programs, six respondents $(5.83 \%)$ come from parallel undergraduate programs, and $74(71.84 \%)$ come from extension graduate programs. 37 respondents $(35.92 \%)$ are male and 66 (64.08\%) are female.

There are 20 respondents (19.42\%) who have never worked or been in an internship program and 83 respondents $(80.58 \%)$ who have worked or been in an internship program. Most respondents have experience working or having been in internship in Public Accounting Firm (KAP), namely, 32 respondents. There are 30 respondents with experience or internship experiences in private companies, 19 respondents with experience of working or being in an apprenticeship in government agencies or institutions and the remaining three respondents have working or apprenticeship experiences in State-Owned Enterprises (BUMN).

\subsection{Profile of Employer Respondents}

There are 51 employers filling out the questionnaires, namely, 24 (47.1\%) males, and 27 (52.9\%) females. Most respondents are aged between 20 and 30 (21 respondents) and most have work experience 10 years or more (26 respondents). Most respondents work in the service industry (19 respondents). The types of service industries include governmental institutions, such as the ministries of finance and taxation, public service agencies, telecommunications services, construction services, publishing, education, and communications. The second industry is manufacturing, with 14 respondents. The types of manufacturing industry include food, cigarette, oil and gas, chemical, mining, and garment industries. The third industry is the financial industry with nine respondents. The types of financial industries include banks, tax consultants, insurers, and capital market industries. The fourth industry is a public accounting firm with six respondents. The last industry is the retail industry with three respondents. The type of retail industry includes shopping mall. 
Most respondents are supervisors. Supervisor position includes tax audit supervisor, heads of section, senior tax accountant, senior tax consultant, senior auditor, senior associates, echelon IV, and senior businessman. Furthermore, the second largest group is manager, with 20 respondents. The manager positions include accounting manager, assistant manager, heads of regional office, head of administrative sub-department, and head of accounting development. The last position is director, with nine respondents including $\mathrm{CFO}$, director of a government agency, director of finance companies, directors in education, and director in the field of publishing.

\subsection{Validity Test and Reliability of Pre-Test Questionnaire}

The questionnaires have passed the pretest stage distributed to 30 respondents, namely, accounting students in a university consisting of students from classes of 2013 through 2016. The pretest is done to measure the accuracy and reliability of the questionnaire before distributing further questionnaires. The tests done by the author are validity and reliability tests. The accuracy of the use of questionnaires to measure the concept of research can be shown by the validity test. The validity test used by the author is factor analysis. This questionnaire is said to be valid if the MSA $\mathrm{KMO}$ value is more than 0.50 . Meanwhile, reliability test uses the measurement of Cronbach's Alpha with value more than 0.7 (Nunnally, 1994) in Ghozali (2012). The test is conducted to measure the consistency level of the items in the questionnaire.

The pretest result shows that every skill question has the KMO MSA of $>0.50$ making it valid. Similarly, Cronbach's Alpha of every skill question has a Cronbach's Alpha of $>0.70$ making it reliable. The results of the validity and reliability tests have been fulfilled, so that the skill section of the questionnaire can be considered valid and reliable.

For the knowledge section, not all questions have the KMO MSA of $>0.50$. There are five questions that have a lower value compared to the MSA KMO limit, making them invalid. This result is likely due to the different backgrounds and situations of each respondent. However, the authors do not omit the item of questions based on the consideration that valid value will be obtained as the number of samples is increased. The Cronbach's Alpha of every knowledge section question has the Cronbach's Alpha of $>0.70$, so they can be considered reliable.

\subsection{Result of Validity Test and Reliability Test of the Questionnaire}

The questionnaire validity test is conducted to measure the reliability of the questions in the questionnaire, while reliability test is done to measure the level of consistency of the question items in the questionnaire. Test results show that validity and reliability elements are met.

\subsection{Mean of Questionnaire of Skills}

The mean of all skills shows the value of more than 4.00, except for two skills, namely, written communication skill $($ mean $=3.78)$ and loyalty to the institution (mean $=3.58)$. This indicates that all skills, except written communication skill and loyalty to the institution, are considered important or very important according to the perception of students.

Honesty $($ mean $=4.59)$, continuous learning $($ mean $=$ 4.56), and work ethics (mean $=4.54$ ) are the three most important skills according to the perception of students, which must be mastered in the professional word.

From employers' expectations, the mean value of all skills shows the mean above 4.00. This suggests that all skills are likely considered important or very important according to the expectations of employers. Work ethics (mean=4.75), teamwork $($ mean $=4.75)$, and time management $($ mean $=4.71)$ are three most important skills according to the employers when hiring employees for accounting works.

\subsection{Mean of Questionnaire of Knowledge}

Knowledge of financial accounting (mean $=4.36$ ), accounting and financial reporting (mean $=4.31$ ), and financial statement analysis (mean $=4.26$ ) are the three most important knowledge skills, according to the perception of students in the professional world. Meanwhile, knowledge of hospitality accounting (mean $=3.13$ ) is less important, according to the perception of students compared to other knowledge.

From employers' perspectives, financial knowledge analysis $($ mean $=4.59)$, Microsoft Office program $($ mean $=$ $4.57)$, and financial accounting knowledge (mean $=4.43)$ are the three most important knowledge skills, according to the employers for the qualification accounting graduates when engaged in the professional world. Meanwhile, knowledge of hospitality accounting (mean $=3.22$ ) is less important, according to the expectation of employers compared to other knowledge skills. This is similar to the perception of students, showing that the knowledge of hospitality accounting is less important for graduates because hospitality accounting courses are not offered to students and not seen as needed for work, according to employers.

\subsection{Comparison of Rank of Skill and Knowledge- based on Students and Employers}

Table 4 shows the comparison of skill rankings from the questionnaires for students and employers. The most 
important skill according to student's perception is honesty. The second highest is continuous learning, the third is work ethics, and the fourth is time management. Meanwhile, the most important skill according to employers' expectations is work ethics, followed by teamwork, time management, and continuous learning.

This ranking supports the results of research by Uyar and Gungormus (2011) who noted that the most needed skills accounting graduates ought to acquire, according to employers, are work ethics and teamwork, while honesty is needed by students. Continuous learning is also needed by graduates, which agrees with the research by Bui and Porter (2010).

Table 5 shows the comparison of the ranking of knowledge from the result of a questionnaire from students and employers. The most important knowledge based on the perception of students is financial accounting, followed by accounting and financial reporting, financial statement analysis, and finance. Meanwhile, the most important level of knowledge according to the expectation of employers is financial statement analysis followed by Microsoft Office program, financial accounting, and accounting and financial reporting.

This ranking supports the research results by Uyar and Gungormus (2011), which show that the most required knowledge for accounting graduates, according to employers, are Microsoft Office program, accounting financial standards, financial statement analysis, and financial accounting knowledge.

\subsection{Analysis of Gap between the Perception of Students and Expectation of Employers}

There an emerging gap between the perception of students and expectation of employers with regard to the skills and knowledge required by accounting graduates. The gap score is obtained from the comparison of perception mean of students and expectation mean of employers in the skill and knowledge sections.

Table 4: Comparison of Rank of Skill for Students and Employers

\begin{tabular}{|c|l|l|}
\hline No. & \multicolumn{1}{|c|}{ Student } & \multicolumn{1}{|c|}{ Employer } \\
\hline 1 & Honesty & Work ethics \\
\hline 2 & Continuous learning & Teamwork \\
\hline 3 & Work ethics & Time management \\
\hline 4 & Problem-solving abilities & Continuous learning \\
\hline 5 & Time management & Comprehension of responsibilities \\
\hline
\end{tabular}

Table 5: Comparison of Rank of Knowledge for Students and Employers

\begin{tabular}{|c|l|l|}
\hline No. & \multicolumn{1}{|c|}{ Student } & \multicolumn{1}{|c|}{ Employer } \\
\hline 1 & Financial accounting & Financial statement analysis \\
\hline 2 & Accounting and financial reporting & Microsoft office program \\
\hline 3 & Microsoft office program & Financial accounting \\
\hline 4 & Financial statement analysis & Accounting and accounting financial standards \\
\hline 5 & Tax regulations & Finance \\
\hline
\end{tabular}

Table 6: Results of Test of Difference of Independent sample t-test

\begin{tabular}{|l|c|c|c|}
\hline Groups & Number of Skills Attribute & Mean & Sig. (2-tailed) \\
\hline Skills & 21 & 4.49 & 0.002 \\
\hline Employer & 21 & 4.25 & 0.002 \\
\hline Student & \multicolumn{3}{|c|}{0.351} \\
\hline Knowledge & 22 & 3.87 & 0.351 \\
\hline Employer & 22 & 3.74 & \\
\hline Student & & & \\
\hline
\end{tabular}


Based on the above table, there is a significant difference between the perception of students and expectation of employers with regard to the skills required by graduates. This possibly suggests that students are focusing attention on knowledge or courses, but put less attention to skills that should also be mastered. The skills having the highest perception of students as regards the skills required of graduates are honesty, continuous learning, and work ethics, while the highest expectation of employers are work ethics, teamwork, and time management. This suggests that students believe that honest attitude is the most important feature to be successful in a professional career, whereas employers prefer work ethic in accordance with the prevailing norms. The second highest ranking of skill, according to students is the willingness to keep learning in order to constantly update information, followed by work ethics. Meanwhile, according to employers, the second highest ranking is teamwork, followed by time management to be able to work effectively and efficiently.

The results of this study confirm the research by Kavanagh and Drennan (2008), who notes that there is a gap between the perception of students and expectation of employers with regard to the skills that accounting graduates should have. There is no significant difference between the perception of students and expectation of employers with regard to the knowledge required by graduates as taught in the curriculum of accounting departments, which is in accordance with the qualifications of employers engaged in the field of accounting work. The result of this study does not go hand in hand, though, with the research by Uyar and Gungormus (2011), which notes that there is a big gap between the perception of students and expectation of employers with regard to the important knowledge to be mastered by graduates caused by a mismatch between university's curriculum and employers' demand.

\section{Conclusions}

This study shows that students perceive that the skills required by accounting graduates are honesty, continuous learning, and work ethics. This means that the most needed skills of graduates according to students is honesty, while the students perceived that the skills least required by graduates are loyalty to the institution, written communication skills, and report writing. The highest expectations of employers with regard to the skills required by graduates are work ethics, teamwork, and time management. This confirms the result of research by Uyar and Gungormus (2011), which notes that the most needed skills of graduates, according to employers, are work ethics and teamwork, while the lowest expectations of the employer with regard to the skills required by graduates are loyalty to the institution, mastering of accounting software, and presentation skills. The highest perceptions of students with regard to the knowledge required by graduates are financial accounting, accounting and financial reporting, and financial statement analysis. This confirms the results of research by Uyar and Gungormus (2011), which states that the most required knowledge of graduates, according to employers are Microsoft Office program, accounting and accounting financial standards, financial statement analysis, and financial accounting, while the lowest perceptions of students with regard to the knowledge required by graduates are hospitality accounting, auditing, and business mathematics. The highest expectations of employers with regard to the knowledge required by accounting graduates are financial statement analysis, Microsoft Office program, and financial accounting, while the lowest expectations of employers with regard to the knowledge required by graduates are hospitality accounting, insurance accounting, and foreign trade operations accounting.

There is a gap between the perception of students and expectation of employers with regard to the skills required by graduates. The results of this study confirm the research by Kavanagh and Drennan (2008), which states that there is an expectation gap between the perception of students and expectation of employers with regard to the important skills accounting graduates ought to have.

There is no gap between the perception of students and expectation of employers with regard to the knowledge required by graduates. This is likely because students and employers have information that is not much different with regard to the needs of knowledge in the field of accounting work. The results of this study are not consistent with the research by Uyar and Gungormus (2011), which states that the gap between the perception of students and expectation of employers with regard to the important knowledge accounting graduates should have is greatly attributed to universities and employers' demand.

This research can be used to help accounting department to focus on and enhance the teaching quality of work ethics, teamwork, and time management skills, as well as knowledge of financial statement analysis, Microsoft Office program, and financial accounting that are considered important by employers so that students can have skills and knowledge that are relevant to their future careers. For the employer, this research can help understand that learning is a continuous process. The existence of a gap between the perception of students and expectation of employers on the skills required by graduates can be overcome by providing guidance on the job so that the skills and knowledge expected by the employers can be developed by accounting graduates over time. This research can also be considered by for students underlining the importance to learn earnestly, while attending lectures and developing themselves outside the classroom, by engaging in extracurricular activities and campus organization so as to equip themselves with 
the skills and knowledge sufficient to face the professional world someday.

This research has several limitations that open up chances for future research. Main limitations come from the samples: first, there was no interview or group discussions of students and employers that could have strengthened the results of this study. The employer samples are only counted 51 respondents, while student samples totaled 118 respondents. This shows an unequal amount of employers and students. The samples used are only students in one geographic location and employer respondents were only reached through Google form, so the researcher cannot be assured whether or not the employer respondents work in the field of accounting. All of these limitations should be remedied in future studies.

\section{References}

Albrecht, W. S., \& Sack, R. J. (2000). Accounting education: charting the course through a perilous. Accounting Education Series, 16(1), 1-72.

Bakar, M. Z. A., \& Bakar, S. A. (2020). Prudent Financial Management Practices among Malaysian Youth: The Moderating Roles of Financial Education. Journal of Asian Finance, Economics, and Business, 7(6), 525-535. https://doi. org/10.13106/jafeb.2020.vol7.no6.525

Bui, B., \& Porter, B. (2010). The expectation-performance gap in accounting education: An exploratory study. Accounting Education: An International Journal, 19(1-2), 23-50.

Dunnette, M. D. (1976). Aptitudes, abilities, and skills. Handbook of industrial and organizational psychology (pp., 473-520). Chicago, IL: Rand McNally.

Ghozali, I. (2012). Multivariate Analysis using Program IBM SPSS 20. Jakarta, Indonesia: Universitas Diponegoro Publisher. [Indonesian]

Gordon, D. (1994). Management System Information. Jakarta, Indonesia: TP. Midas Surya Grafindo. [Indonesian]

Jackling, B., \& de Lange, P. (2009). Do accounting graduates' skills meet the expectations of employers? A matter of convergence or divergence. Accounting Education: An International Journal, 18(4-5), 369-385.
Koh, H.C., \& Woo, E.S. (1998). The Expectation Gap in Auditing. Managerial Auditing Journal, 13(3), 147-154.

Kavanagh, M. H., \& Drennan, L. (2008). What skills and attributes does an accounting graduate need? Evidence from student perceptions and employer expectations. Accounting \& Finance, 48(2), 279-300.

Keraf. (2001). On the knowledge. Jakarta, Indonesia: Kanisius. [Indonesian]

Klibi, M. F., \& Oussii, A. A. (2013). Skills and attributes needed for success in accounting career: Do employers' expectations fit with students' perceptions? Evidence from Tunisia. International Journal of Business and Management, 8(8), 118. DOI:10.5539/ ijbm.v8n8p118

Kumari, N. (2014). Most to Least Preferred Parameters Affecting the Quality of Education: Faculty Perspectives in India. Journal of Asian Finance, Economics and Business, 1(3), 37-42. https:// doi.org/10.13106/jafeb.2014.vol1.no3.37.

Low, M., Botes, V., De La Rue, D., \& Allen, J. (2016). Accounting employers' expectations-the ideal accounting graduates. Accounting Employers' Expectations - The Ideal Accounting Graduates. e-Journal of Business Education \& Scholarship of Teaching, 10(1), 36-57.

Nadler, G. (1986). Breakthrough thinking. Baton Rouge, LA: Southern University.

Polak, M. (1976). Sociology: A Brief Introduction. Yogjakarta, Indonesia: Pustaka Pelajar. [Indonesian]

Robbins, S. P., Judge, T. A. (2008). Organizational Behaviour. Jakarta, Indonesia: Salemba Empat. [Indonesian]

Tempone, I., \& Martin, E. (2003). Iteration between theory and practice as a pathway to developing generic skills in accounting. Accounting Education, 12(3), 227-244.

Trisnaningsih, S., Sutrisno, S., Permatasari, Y., Hendra, F. H., \& Sulistyowati, E. (2020). Contingency Model to Increase the Uptake of Higher Education Graduates in the Job Market. Journal of Asian Finance, Economics, and Business, 7(4), 197-203. https://doi.org/10.13106/jafeb.2020.vol7.no4.197

Uyar, A., \& Gungormus, A. H. (2011). Professional knowledge and skills required for accounting majors who intend to become auditors: Perceptions of external auditors. Business and Economics Research Journal, 2(3), 33-49. 